\title{
PREDICTION OF BACTERIAL VULVOVAGINITIS IN GIRLS AT DIFFERENT TANNER STAGES OF SEXUAL DEVELOPMENT
}

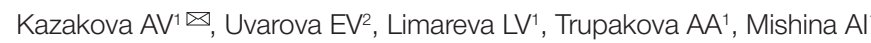

${ }^{1}$ Samara State Medical University, Samara, Russia

2 Kulakov Federal Research Center for Obstetrics, Gynecology, and Perinatology, Moscow, Russia

\begin{abstract}
At present, there is a paucity of research studies that comprehensively investigate the factors causing vulvovaginitis in young females. The aim of this work was to propose an algorithm for predicting the risk of vulvovaginitis in young girls and adolescents. The study recruited 252 healthy girls, who were stratified into a few groups depending on their sexual development on the Tanner scale. The composition of vaginal microbiota was determined in all the participants using realtime polymerase chain reaction (PCR); distribution of allele and genotype frequencies was assessed for the polymorphic variants of genes coding for pro- and anti-inflammatory cytokines. Based on the obtained data, we created a functional model for predicting the risk of vulvovaginitis in girls at different stages of sexual development. Favorable risk factors for Tanner I girls included predominance of obligate anaerobes in vaginal microbiota and the polymorphic IL10 variant (C-819T) homozygous for $\Pi$. The sensitivity of the model was $80 \%$, its specificity was $78 \%$. Favorable risk factors for prepubertal and pubertal girls included predominance of aerobes in the composition of vaginal microbiota and the presence of the TT allele in the polymorphic IL10 gene variant (C-3953T). The sensitivity of the model was $58.3 \%$, whereas specificity, $94.1 \%$. This study provides the rationale conforming with the principles of evidence-based medicine for using prevention measures in the groups at risk for vulvovaginitis at young age. The proposed measures allowed us to reduce the relapse rate of bacterial vulvovaginitis threefold.
\end{abstract}

Keywords: vulvovaginitis, teenagers, prediction, prevention, evidence-based medicine

Author contribution: Kazakova AV — study concept and design, data acquisition and analysis, manuscript draft; Uvarova EV — study concept and design, manuscript revision; Limareva LV — study concept and design, manuscript revision; Trupakova AA, Mishina Al — data acquisition and analysis, manuscript draft.

Compliance with ethical standards: the study was approved by the Ethics Committee of Samara State Medical University (Protocol № 5 dated April 20, 2018). Informed consent was obtained from the parents of the study participants.

$\triangle$ Correspondence should be addressed: Anna V. Kazakova

Lesnaya, 31, kv. 40, Samara, 443110; amigo14021980@yandex.ru

Received: 27.09.2019 Accepted: 17.10.2019 Published online: 29.10.2019

DOI: 10.24075/brsmu.2019.070

\section{СПОСОБ ПРОГНОЗИРОВАНИЯ БАКТЕРИАЛЬНОГО ВУЛЬВОВАГИНИТА У ДЕВОЧЕК В ЗАВИСИМОСТИ ОТ СТАДИИ ПОЛОВОГО РАЗВИТИЯ СОГЛАСНО ШКАЛЕ ТАННЕРА}

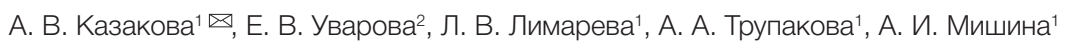

${ }^{1}$ Самарский государственный медицинский университет, Самара, Россия

${ }^{2}$ Научный центр акушерства, гинекологии и перинатологии имени В. И. Кулакова, Москва, Россия

На современном этапе мало научных работ по всестороннему изучению факторов, приводящих к вульвовагиниту у девочек. Целью исследования было разработать программу прогнозирования риска вульвовагинита у девочек в детском и подростковом возрасте. В исследовании приняли участие 252 здоровые девочки, которых разделили на группы в зависимости от стадии полового развития по Таннеру. У всех было проведено определение состава микрофлоры влагалища методом полимеразной цепной реакции (ПЦР) в режиме реального времени и распределение частот аллелей и генотипов полиморфных вариантов генов провоспалительных и противовоспалительных цитокинов. На основании полученных данных разработана рабочая модель по прогнозированию развития вульвовагинитов у девочек с учетом стадии полового развития. Благоприятными факторами для девочек на I стадии полового развития были преобладание облигатных анаэробов в микробиоте влагалища и гомозигота TT полиморфного варианта гена IL10 (C-819T). Чувствительность модели составила 80\%, специфичность - 78\%. Для девочек в препубертатном и пубертатном периодах - преобладание аэробов в микробиоте влагалища и гомозигота TT полиморфного варианта гена IL 10 (C-3953T). Чувствительность модели составила 58,3\%, специфичность 94,1\%. С позиции доказательной медицины обоснована необходимость просилактических мероприятий в группах риска по развитию вульвовагинитов в детском возрасте, позволяющая снизить частоту рецидивов бактериального вульвовагинита в 3 раза.

Ключевые слова: вульвовагинит, подростки, прогнозирование, профилактика, доказательная медицина

Информация о вкладе авторов: А. В. Казакова - концепция и дизайн исследования, сбор и обработка материала, статистическая обработка, написание и редактирование статьи; Е. В. Уварова - концепция и дизайн исследования, редактирование рукописи; Л. В. Лимарева - концепция и дизайн исследования, редактирование рукописи; А. А. Трупакова, А. И. Мишина - сбор и обработка материала, написание статьи.

Соблюдение этических стандартов: исследование одобрено этическим комитетом Самарского государственного медицинского университета (протокол № 5 от 20 апреля 2018 г.). Родители всех участников исследования подписали добровольное информированное согласие на анкетирование и медицинское вмешательство.

$\triangle$ Для корреспонденции: Анна Владимировна Казакова,

ул. Лесная, д. 31, кв. 40, г. Самара, 443110; amigo14021980@yandex.ru

Статья получена: 27.09.2019 Статья принята к печати: 17.10.2019 Опубликована онлайн: 29.10.2019

DOI: $10.24075 /$ vrgmu.2019.070

In recent years, there have been reports of declining health statistics and the growing incidence of reproductive and gynecological disorders in children and adolescents [1-4]. Due to its high prevalence in children of all ages, genital inflammation is regarded as a clinically important problem [5-7]. Vulvovaginitis is the most common type of inflammatory genital conditions (84.2\%) in girls under 10 years of age [8-10].
In young females, the main susceptibility factors include hormonal changes, lifestyle, poor intimate hygiene, and genetically determined features of immune response [11-14]. Early age of sexual initiation is one of the factors disrupting reproductive health and provoking dysbiosis of vaginal microbiota [15]. A greater threat is posed by self-medication practices and delays in seeking medical advice. 
Local immunity response affects the composition of vaginal microbiota and plays a leading role in driving inflammation [16]; however, the mechanisms maintaining immune tolerance remain understudied $[17,18]$.

Hygiene is an important aspect of sexual education. However, although hygiene practices are well-established and based on solid scientific evidence, hygiene habits differ across regions and among individuals with different social background. Unlike genetic factors that affect physical development and shape immune response, intimate hygiene and reproductive behavior can be modified to improve health. New approaches are needed to predict and prevent the risk of vulval and vaginal inflammation in young females.

The aim of this study was to develop a program for predicting the risk of vulval and vaginal inflammation in girls at different stages of sexual development. For that, we identified social, hygienic, clinical, and molecular-genetic prognostic markers of vulvovaginitis; proposed a prognostic model for predicting vulvovaginitis in girls; assessed the clinical effect of original prevention measures against vulval and vaginal inflammation in girls at different stages of sexual development.

\section{METHODS}

The study was conducted at the Outpatient Pediatric Department № 1 (Samara City Clinic № 13) from February 2013 to August 2016. The study recruited 252 healthy girls presenting for an annual check-up at the Clinic. All participants were stratified into a few groups according to their age. Age intervals reflected the stages of sexual development on the Tanner scale. Considering that the composition of vaginal microbiota in young girls is age-dependent, prognostic models were built for different sexual development stages: group 1 included 74 Tanner I girls and group 2, 178 Tanner II-V girls.

The following inclusion criteria were applied: age from 2 to 17 years, the absence of health complaints; no somatic or gynecological disorders; normal physical, psychological and sexual development.

Exclusion criteria were as follows: the use of antibacterial drugs in a month preceding the examination; acute inflammatory diseases at the time of examination and swab collection.

All girls and their mothers were interviewed using a questionnaire. Questions were asked about hygiene habits of mothers and their daughters and sexual behavior of the participants. Additionally, we studied 226 vaginal and 226 buccal swabs obtained from the girls.

Before the tests, complaints were taken, physical (height, weight, BMI) and sexual development (Tanner stage, external genital examination) was evaluated. Intimate hygiene practices were also assessed.

Swabs were collected from vaginal vestibule mucosa or the posterior fornix through hymenal rings using a standard swab kit. DNA of opportunistic microorganisms (OMs) was assayed in real-time PCR using a Femoflor-17 reagent kit (DNA-Technology; Russia) for profiling the composition of genitourinary microbiota. The following parameters were assessed: quality control of sample collection (SCQC); total bacterial mass (TBM); the presence of mollicutes (Mycoplasma hominis, Ureaplasma spp.), yeast (Candida spp.), bacteria (Lactobacillus spp., Enterobacterium spp., Streptococcus spp., Staphylococcus spp., Gardnerella vaginalis / Prevotella bivia / Porphyromonas spp., Eubacterium spp., Sneathia spp. / Leptotrichia spp. / Fusobacterium spp., Megasphaera spp. / Veillonella spp. / Dialister spp., Lachnobacterium spp. / Clostridium spp., Mobiluncus spp. I Corinebacterium spp.,
Peptostreptococcus spp., Atopobium vaginae), and pathogens (Mycoplasma genitalium). SCQC was valid in all cases, confirming the objectivity of the subsequent results analysis.

Considering the immune mechanisms underlying vulval and vaginal inflammation, we studied the distribution of allele and genotype frequencies for the following polymorphic variants of anti- and pro-inflammatory cytokine genes using PCR: IL1 $\beta$ (T-31C), IL1 $\beta$ (T-511C), IL1 $\beta(C-3953 T), I L 1 \beta$ (G-1473C) in the IL1 $\beta$ gene; IL6 (C-174G) in the IL6 gene; TNF $\alpha$ (G-308A) in the TNF $\alpha$ gene; IL10 (G-1082A), IL10 (C-592A), IL10 (C-819T) in the IL10 gene; TGF $\beta 1$ (Arg25Pro) in the TGF $\beta$ gene in order to identify the role of polymorphisms of immune response genes in the development and clinical course of the pathology.

Decision trees were constructed using the classification and regression tree algorithm (CART). Briefly, each decision tree node had two children. In each step, the rule generated by the node split the dataset into two subsets: the one where the rule was satisfied and the other where it was not. The computer algorithm selected the attribute on which the node was split, determined the splitting value and decided when to stop tree bulding. The optimal rule was selected using the function for splitting quality assessment based on the Gini index [19].

The following groups of attributes were used to build our decision trees:

- information about vaginal microbiota obtained with the Femoflor kit (expressed as gram-equivalents and as percentage relative to TBM);

- results of molecular-genetic tests of polymorphic variants of genes coding for the selected cytokines;

- information about hygiene habits obtained from questionnaires (intimate washing, showering, changing underwear regularly, etc.).

Additionally, we calculated the ratio of lactobacilli (aerobes) to obligate anaerobes.

\section{Testing the proposed recommendations on prevention}

The obtained data were used to develop a set of prevention measures. To test their effect, we conducted a prospective study that enrolled 167 girls. The main group $(n=52)$ was given original recommendations proposed in this work; the control group ( $n=115$ ) received standard recommendations from a pediatric gynecologist. The girls were followed up for one year; then, the obtained data were statistically analyzed in compliance with the principles of evidence-based medicine [20].

\section{Statistical analysis}

The obtained data were saved to and processed in Microsoft Excel. Statistical analysis was performed using the SPSS 21 software (IBM SPSS Statistics; USA, license 20130626-3). The applied methods of descriptive statistics included calculation of the arithmetic mean and its deviation $(\mathrm{M} \pm m)$ or, in case of skewed distribution, the median and the quartile range. Information about the analyzed microorganisms was saved to a table; we specified the number of girls who had the identified species and the mean concentration of the microorganism expressed as a decadic logarithm (lg). Mean values were calculated only for the subgroup of girls who had the microorganism. For such variables as past infections, hygiene practices and genotypes, contingency tables were constructed and Pearson's chi-squared was calculated.

The quality of classification was assessed using ROCcurves and evidence-based medicine criteria: sensitivity and specificity. 


\section{RESULTS}

Considering that the composition of vaginal microbiota depends on age, we built models for predicting the risk of vulvovaginitis in 2 groups of girls at different Tanner stages: group 1 (Tanner 1) and group 2 (Tanner II-V).

The prognostic model for Tanner I girls is shown in Fig. 1. The presence of the following two prognostic markers was considered a favorable risk factor: predominance of obligate anaerobes in the composition of vaginal microbiota and the polymorphic IL10 variant (C-819T) homozygous for TT. If any of these two conditions was not satisfied or lactobacilli dominated the composition of vaginal microbiota or there was at least one $\mathrm{C}$ allele in the IL10 gene, this led to an increased risk of vulvovaginitis in girls from group 1 .

The quality of prediction was assessed by constructing a contingency table for observed and predicted outcomes (Table 1). Nine predictions were false-positive (vulvovaginitis was predicted by the model but the girl turned out to be healthy). Three predictions were false-negative. In group 1, the sensitivity of the applied method was $80 \%$, whereas specificity - 78\%.

Based on the constructed decision tree, the prediction algorithm for Tanner I girls was as follows:

1. If the proportion of aerobes was $>34 \%$, then the risk of vulvovaginitis was estimated as probable. If the proportion of aerobes was $\leq 34 \%$, the algorithm proceeded to step 2 .

2. If locus 819 of the IL10 gene was homozygous for the $\Pi T$ allele, then the risk of vulvovaginitis was considered minimal. If this locus was homozygous for the $\mathrm{C}$ allele (the CC genotype) or heterozygous (the CT genotype), then the risk of vulvovaginitis was estimated as high.

The prognostic model for predicting the risk of vulvovaginitis in Tanner $\|-V$ girls is shown in Fig. 2. Favorable risk factors in prepubertal and pubertal girls included aerobic predominance in the composition of vaginal microbiota and the presence of the $\Pi$ allele in the polymorphic IL10 gene variant (C-3953T). If any of these two conditions was not satisfied (the smaller proportion of aerobes, the presence of at least one $\mathrm{C}$ allele in the IL10 gene), then an increased risk of vulvovaginitis in girls from group 2 was inferred. The sensitivity of the prognostic models was $58.3 \%$, whereas specificity, $94.1 \%$.

The prediction algorithm for Tanner II-V girls was as follows:

1. If the aerobic content expressed as genomic equivalents was $\leq 6.15$, the algorithm proceeded to step 2. If the aerobic content expressed as genomic equivalents was $>6.15$, the algorithm proceeded to step 4.

2. If the IL10 (C-592A) gene was homo- or heterozygous for at least one A allele, the risk of vulvovaginitis was estimated as minimal. If the polymorphic IL10 (C-592A) gene carried the CC genotype, the algorithm proceeded to step 3.

3. If a girl showered every day, she was at minimum risk for vulvovaginitis. If showering was not regular, the risk for vulvovaginitis was estimated as high.

4. If the IL1 $\beta$ (C-3953T) gene had the $\Pi T$ genotype, the risk for vulvovaginitis was minimal. If this gene had the CT or CC genotype, we proceeded to step 3 .

It is known that a substitution of the $T$ allele for the $\mathrm{C}$ allele at position -3953 in the IL1 $\beta$ gene results in a decreased production of proinflammatory IL $1 \beta$ and is clinically associated with a weaker immune response to an antigen. In combination with inadequate hygiene practices, this factor can be decisive in triggering inflammation.

When the A allele is substituted for the $\mathrm{C}$ allele at position -592 of the IL10 gene, the production of IL10 increases. IL10 is an anti-inflammatory cytokine; its overproduction during immune response to infection can undermine the effect of immune defense mechanisms. Although IL10 overproduction is determined genetically, the decision tree demonstrates that this factor exerts its negative impact only in case of poor hygiene practices.

Summing up, the use of decision trees allowed us to create a convenient and functional prognostic model for assessing the risk of vulvovaginitis and to analyze different allele combinations and their interplay.

Based on the reliable risk factors identified by our regression model, we proposed the following prevention measures for the girls over 16 years of age at risk for vulvovaginitis.

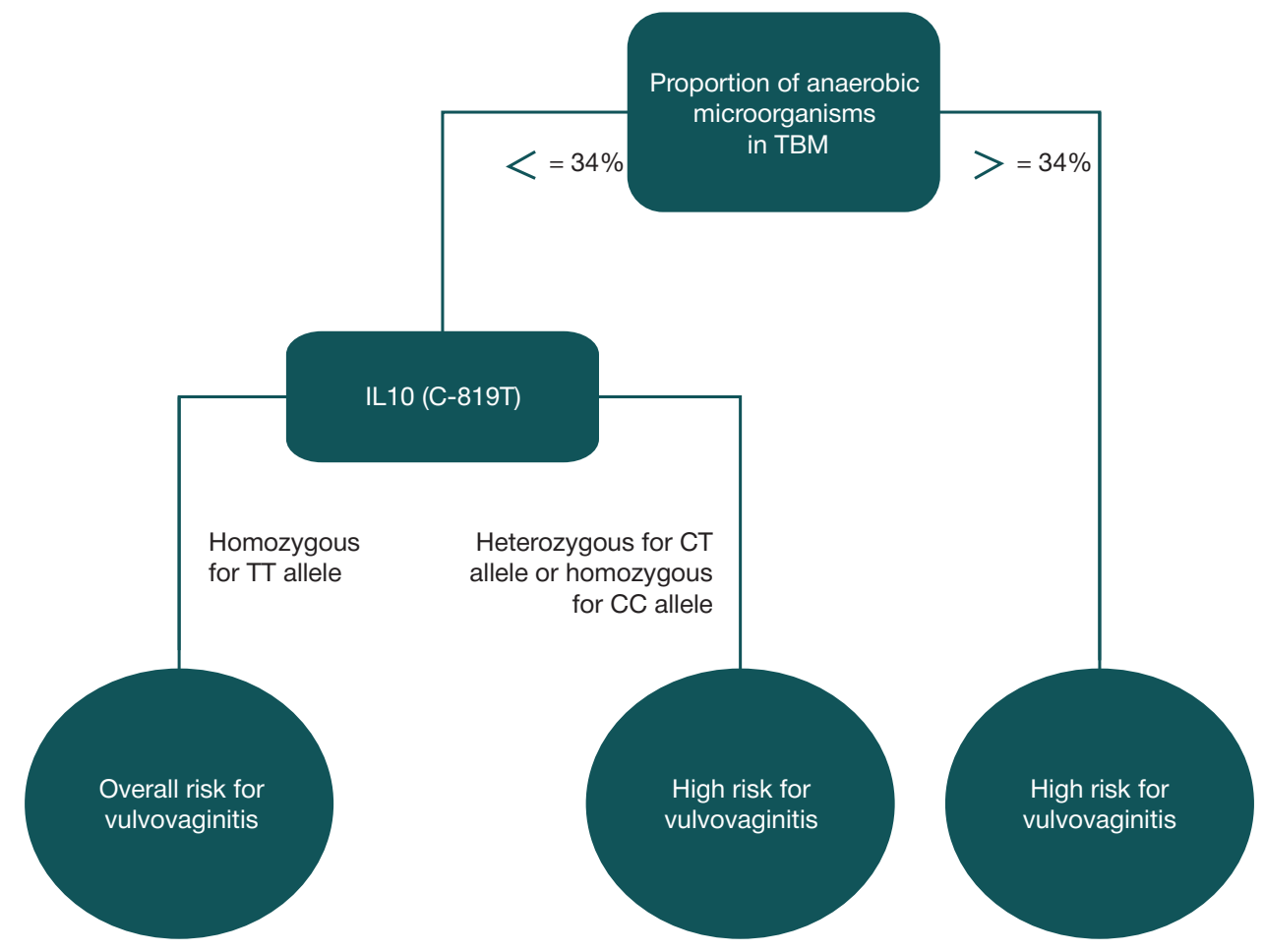

Fig. 1. The algorithm for assessing the risk of bacterial vulvovaginitis in Tanner I girls 
Table 1. Quality of prediction

\begin{tabular}{|l|c|c|c|}
\hline \multirow{2}{*}{ Observed } & \multicolumn{2}{|c|}{ Predicted by the model } & \multirow{2}{*}{ Total } \\
\cline { 2 - 4 } & Healthy & Vulvovaginitis & 41 \\
\hline Healthy & 32 & 9 & 12 \\
\hline Vulvovaginitis & 3 & 21 & 56 \\
\hline Total & 35 & 12 & 56 \\
\hline
\end{tabular}

Tanner I girls were recommended 1) seeking medical advice with medical professionals immediately if genitourinary or ENT infections were noticed; 2) showering daily and changing underwear regularly; 3) washing the intimate area twice a day; 4) seeing a gynecologist once a year.

Tanner II-V girls were recommended 1) seeking medical advice with an allergist and regular check-ups in case of any allergies; 2) showering daily and changing underwear regularly; 3) washing the intimate area twice a day; 4) sexual initiation not earlier than 17 years; 5) safe sexual behavior: using reliable methods of contraception, sticking to one sex partner; 6) seeing a gynecologist once a year.

To assess the effect of our original prevention measures, we calculated the values for a number of quantitative indicators according to the recommendations by Kotelnikov GP and Shpigel AS [20]. A contingency table was constructed for additional prevention measures and relapses (Table 2).

Study results are shown in Tables 3 and 4. The 2 main indicators used to calculate the effect of prevention measures were relapse rates in the main (treatment) and control groups (RRM, RRC):

$$
\begin{aligned}
& \mathrm{RRM}=a /(a+b) ; \\
& \mathrm{RRC}=c /(c+d) .
\end{aligned}
$$

95\% $\mathrm{Cl}$ for RRM and RRC was calculated using the Wilson method.

RRM was 17.3\% (95\% Cl: 9.4-29.7\%); RRM, 34.8\% (95\% Cl: 26.7-43.9\%); $p=0.035$ (Pearson's $\chi^{2}$ was applied).
The difference between the relapse rates in the main and control groups was estimated using the values of relative and absolute risk reduction (RRR, ARR).

$\mathrm{RRR}$ represented the decrease in the relapse rate in the main group relative to the control group:

$$
R R R=(R R C-R R M) / R R C .
$$

ARR represented the difference between the relapse rates in the main and control groups:

$$
\mathrm{ARR}=\mathrm{RRC}-\mathrm{RRM}
$$

95\% Cl for RRR was calculated using the method proposed by M. Gardner and D. Altman; 95\% Cl for ARR was calculated using the method proposed by L. Bjerre and J. LeLorier [21, 22].

In this study, the relapse rate in the main group dropped by 17.5\% (95\% Cl: 2.7-29.5\%), i.e., twofold:

$$
\operatorname{RRR}=(34.8-17.3) / 34.8 \times 100 \%=50.2 \% .
$$

OR for the relapse rate with $\mathrm{Cl}$ calculated according to J. Bland and D. Altman, was 0.39 (95\% Cl: 0.17-0.89).

Subsequently, we calculated the number of patients (NP) who had to follow the proposed prevention strategy in order to prevent the poor outcome in one patient. NP equals the reciprocal of $A R R$ (if $A R R$ is expressed as percentage, then $\mathrm{NP}=100 \%$ / ARR); its $\mathrm{Cl}$ is reciprocals of the upper and lower limits of $95 \% \mathrm{Cl}$ : ARR.

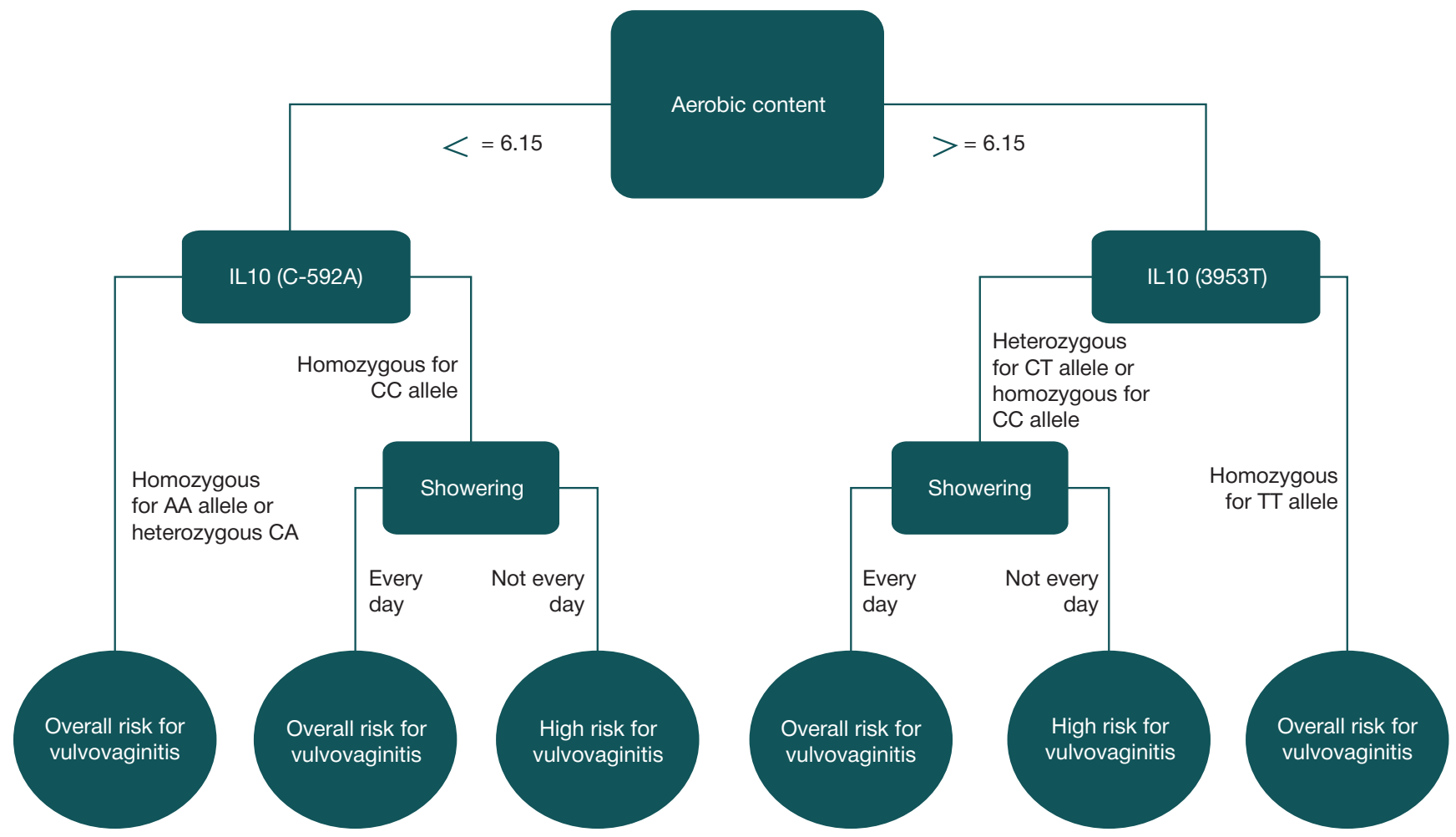

Fig. 2. The algorithm for assessing the risk of non-specific genital inflammation in Tanner II-V girls 
Table 2. The contingency table

\begin{tabular}{|l|c|c|}
\hline \multicolumn{1}{|c|}{ Groups } & Relapse & Notal relapse \\
\hline Main group_-prevention measures proposed in the study & $a$ & $b$ \\
\hline Control group - follow-up observation & $c$ & $d$ \\
\hline Total & $a+c$ & $b+d$ \\
\hline
\end{tabular}

Note: $a$ - relapse, $b$ - no relapse, $c$ — relapse, $d$ - no relapse.

Table 3. Outcomes of the proposed prevention measures

\begin{tabular}{|l|c|c|}
\hline \multirow{2}{*}{ Groups } & \multicolumn{2}{|c|}{ Effect of prevention measures } \\
\cline { 2 - 4 } & Relapse of vulvovaginitis & No relapse observed \\
\hline Main group: prevention measures applied & 9 & 43 \\
\hline Control group: observation & 40 & 75 \\
\hline Total & 49 & 115 \\
\hline
\end{tabular}

Table 4. Indicators of intervention effect

\begin{tabular}{|l|c|c|}
\hline \multicolumn{1}{|c|}{ Indicator } & Abbreviation & Value, \% \\
\hline Relapse rate in the main group & RRM & 17.3 (9.4-29.7) \\
\hline Relapse rate in the control group & RRR & $50.8(26.7-43.9)$ \\
\hline Relative risk reduction & ARR $(5.1-73.9)$ \\
\hline Absolute risk reduction & NP & 17.5 (2.7-29.5) \\
\hline Number of patients to be treated & RR & 6(3-38) \\
\hline Relative risk & OR & $0.5(0.26-0.95)$ \\
\hline Odds ratio & $\chi^{2}$ & $0.39(0.17-0.89)$ \\
\hline$\chi^{2}$ with Yates' correction & $p$ & 4.47 \\
\hline$p$ & & 0.035 \\
\hline
\end{tabular}

$$
N P=100 \% / C A P=100 \% / 17.5 \%=6 .
$$

This means that if 6 girls at risk for vulvovaginitis strictly follow our recommendations, then at least one of them will not develop vulvovaginitis within a year. It should be noted that for our sample size, Cl for NP is 3 to 38 individuals.

Comparison of relapse rates in the group that was given original recommendations and the statistics on the prevalence of vulvovaginitis in the population confirmed the positive effect of the proposed prevention strategy. Relapses occurred in 17.4\% of the girls form the group at risk for the pathology (ClopperPearson $95 \% \mathrm{Cl}$ was 8.6-31.4\%). In the follow-up period, 6 girls developed clinical symptoms of nonspecific vulvovaginitis; the vaginal swabs obtained from 3 of those 6 girls revealed bacterial contamination. Those figures differed significantly $(p<0.001)$ from the population data; the latter suggest that on average, relapses of lower genital tract inflammation in this age group occur in $60 \%$ of cases $[23,24]$.

\section{DISCUSSION}

The obtained data are consistent with the results of another study demonstrating that, as a rule, vulvovaginitis is caused by nonspecific factors and that adequate hygiene practices have the best prevention effect against bacterial vulvovaginitis [25].

The importance of good feminine hygiene products and adequate intimate hygiene practices is emphasized in another study reporting that $25 \%$ of the respondents use vaginal douching, 29\% use sprays, and 19\%, topical antiseptics in order to prevent STD, which increases the risk of vaginal microbiota dysbiosis [26].

A cross-sectional study conducted in Slovakia has identified the most common intimate hygiene malpractices in female adolescents and young women between 15 and 22 years of age, including total hair removal in the intimate area (95\%), bad hygiene before and after intercourse (38\%), wearing a damp bathing suit instead of changing it to a dry one (58.06\%), wearing unsuitable underwear. Younger respondents (15 to 19 years) and women with a lower educational status had worse hygiene habits that could be associated with unawareness of the related intimate health problems [27].

The analysis of the literature on the dysbiosis of vaginal microbiota at young age reveals no consensus on the predictors of this pathology.

Studies of vaginal microbiota covering its age-related aspects are scarce and do not often account for the stage of reproductive system development a participant is undergoing at the moment.

The role of polymorphisms and the expression of cytokine genes in driving the pathology is understudied.

There is a need for a comprehensive study of endogenous (vaginal microbiota, polymorphisms of immune response genes, somatic health) and exogenous factors (behavior) contributing to and driving vulvovaginal inflammation.

\section{CONCLUSIONS}

1. The proposed models for predicting genital inflammation account for Tanner stages of sexual development and can be used in girls between 2 and 17 years of age to decide on the treatment or prevention strategy. 2. This study provides the rationale conforming with the principles of evidence-based medicine for using prevention measures in the groups at risk for vulvovaginitis at young age. These measures allow reducing the relapse rate of bacterial vulvovaginitis threefold. 3. The proposed algorithm can be further improved using modern software and the personalized approach for the identification of groups at risk. 
1. Alvarez-Olmos Ml, et al. Vaginal lactobacilli in adolescent: presence and relationship to local and systemic immunity, and to bacterial vaginosis. Sex Transm Dis. 2004; (31): 393-400.

2. Amjadi $F$, et al. Role of the innate immunity in female reproductive tract. Adv Biomed Res. 2014; (3): 1.

3. Attieh E, Maalouf $\mathrm{S}$, Roumieh D, et al. Feminine hygiene practices among female patients and nurses in Lebanon. Reproductive Health. 2016; 13 (1): 59.

4. Beyiter I, Kavukcu S. Clinical presentation, diagnosis and treatment of vulvovaginitis in girls: a current approach and review of the literature. World J Pediatr. 2017; 13 (2): 101-5.

5. Kazakova A. V. Programma profilaktiki bakterial'nogo vul'vovaginita u devochek v zavisimosti ot stadii polovogo razvitija [dissertacija]. Samara, 2019. Russian.

6. Prilepskaya VN, Letunovskaya AB, Donnikov AE. Mikrobiocenoz vlagalishha i polimorfizm genov citokinov kak marker zdorov'ja zhenshhiny. Ginekologija. 2015; (2): 4-13. Russian.

7. Altun I, Cinar ND, Dede C. Hygiene behaviour in university students in Turkey. J Pak Med Assoc. 2013; 63 (5): 585-9.

8. Grinevich EV. Harakteristika mikrobiocenozov vlagalishha, kishechnika i mochevyvodjashhih putej pri vul'vovaginitah u devochek rannego vozrasta $v$ zavisimosti ot razlichnyh faktorov riska [dissertacija]. Smolensk, 2005. Russian.

9. Kazakova AV, Spiridonova NV, Uvarova EV, Komarova MV Bezrukova AA. Mnogomernyj analiz prediktorov patologicheskih vydelenij iz polovyh putej v zavisimosti ot obraza zhizni studentok. Reproduktivnoe zdorov'e detej i podrostkov. 2016; (6): 90-7. Russian.

10. Chebotareva YuYu, Kostoeva ZA, Grigorjan AA. Anatomofunkcional'nye osobennosti reproduktivnoj sistemy pri vul'vovaginitah u chasto bolejushhih detej. Kubanskij nauchnyj medicinskij vestnik. 2013; (1): 178-81. Russian.

11. Karlsson CL, Molin G, Cilio CM, et al. The pioneer gut microbiota in human neonates vaginally born at terma pilot study. Pediatr Res. 2011; (70): 282-6.

12. Kayserova J, et al. Serum immunoglobulin free light chains in severe forms of atopic dermatitis. Clin Immunol. 2010; (71): 312-6.

13. Kestřánek J, Jílek $P$, Matula $V$, et al. Jaký je aktuální stav diagnostiky vulvovaginálního dyskomfortu v České Republice? Česká Gynekologie. 2013; 78 (6): 522-7.

14. Mitchell C, Moreira C, Fredricks D, et al. Detection of fastidious vaginal bacteria in women with HIV infection and bacterial vaginosis. Infectious Diseases in Obstetrics and Gynecology. 2009; (12) Access mode: https://www.ncbi.nlm.nih.gov/pmc/ articles/PMC2777244/. (Date of access: 22.10.19).

15. Zhizhko EV, Chiganovoj SD. Molodaja sem'ja: problemy perspektivy social'noj podderzhki. Krasnojarsk: RUMC JuO, 2011; 145 s. Russian.

16. Fischer GO. Chronic vulvitis in prepubertal girls. Aust J Dermatology. 2010; (51): 118-23.

17. Lewis WG, Robinson LS, Perry J, et al. Hydrolysis of secreted sialoglycoprotein immunoglobulin A (IgA) in ex vivo and biochemical models of bacterial vaginosis. J Biol Chem. 2012; 287 (3): 2079-89.

18. Ott MA, Ofner S, Fortenberry JD. Beyond douching: use of feminine hygiene products and STI risk among young women. $J$ Sex Med. 2009; (6): 1335-40.

19. Kohreidze NA, Gurkin YuA, Kutusheva GF, i dr. Vul'vovaginit v rannem detstve. SPb., 2017; 23 s. Russian.

20. Zijadullaev UH. Sostojanie immuniteta pri kandidoznom vul'vovaginite u devochek podrostkov. Problemy reprodukcii. 2014; (2): 32-4. Russian.

21. Gardner MJ, Altman DG. Statistics with confidence. BMJ publications. Reprint. 1994: 51-52.

22. Bjerre LM, LeLorier J. Expressing the magnitude of adverse effects in case-control studies: "the number of patients needed to be treated for one additional patient to be harmed". BMJ. 2000; (320): 503-6.

23. Zdravoohranenie v Rossii. 2017: Statisticheskij sb. Rosstat. Moskva, 2017; 170 s. Dostupno po ssylke: [http://www.gks.ru/ free_doc/doc_2017/zdrav17.pdf]. Russian.

24. Kirillova EN, Pavlyukova SA, Akulich NS. Vul'vovaginit u detej. Medicinskij zhurnal. 2017; (2): 151-3. Russian.

25. Brabin $L$, Roberts $S A$, Fairbrother $E$, et al. Factors affecting vaginal $\mathrm{pH}$ levels among female adolescents attending genitourinary medicine clinics. Sex Transm Infect. 2005; (81): 483-7.

26. Brotman RM, Erbelding EJ, Jamshidi RM, et al. Findings associated with recurrence of bacterial vaginosis among adolescents attending sexually transmitted diseases clinics. $J$ Pediatr Adolesc Gynecol. 2007; (20): 225-31.

27. Donders GG, et al. Vaginal cytokines in normal pregnancy. American journal of obstetrics and gynecology. 2003; (189): $1433-8$.

\section{Литература}

1. Alvarez-Olmos $\mathrm{Ml}$, et al. Vaginal lactobacilli in adolescent: presence and relationship to local and systemic immunity, and to bacterial vaginosis. Sex Transm Dis. 2004; (31): 393-400.

2. Amjadi $F$, et al. Role of the innate immunity in female reproductive tract. Adv Biomed Res. 2014; (3): 1.

3. Attieh E, Maalouf $\mathrm{S}$, Roumieh $\mathrm{D}$, et al. Feminine hygiene practices among female patients and nurses in Lebanon. Reproductive Health. 2016; 13 (1): 59.

4. Beyiter I, Kavukcu S. Clinical presentation, diagnosis and treatment of vulvovaginitis in girls: a current approach and review of the literature. World J Pediatr. 2017; 13 (2): 101-5.

5. Казакова А. В. Программа профилактики бактериального вульвовагинита у девочек в зависимости от стадии полового развития [диссертация]. Самара, 2019.

6. Прилепская В. Н., Летуновская А. Б., Донников А. Е. Микробиоценоз влагалища и полиморфизм генов цитокинов как маркер здоровья женщины. Гинекология. 2015; (2): 4-13.

7. Altun I, Cinar ND, Dede C. Hygiene behaviour in university students in Turkey. J Pak Med Assoc. 2013; 63 (5): 585-9.

8. Гриневич Е. В. Характеристика микробиоценозов влагалища, кишечника и мочевыводящих путей при вульвовагинитах у девочек раннего возраста в зависимости от различных факторов риска [диссертация]. Смоленск, 2005.

9. К Казакова А. В., Спиридонова Н. В., Уварова Е. В., Комарова М. В., Безрукова А. А. Многомерный анализ предикторов

патологических выделений из половых путей в зависимости от образа жизни студенток. Репродуктивное здоровье детей и подростков. 2016; (6): 90-7.

10. Чеботарева Ю. Ю., Костоева З. А., Григорян А. А. Анатомофункциональные особенности репродуктивной системы при вульвовагинитах у часто болеющих детей. Кубанский научный медицинский вестник. 2013; (1): 178-81.

11. Karlsson CL, Molin G, Cilio CM, et al. The pioneer gut microbiota in human neonates vaginally born at terma pilot study. Pediatr Res. 2011; (70): 282-6.

12. Kayserova $\mathrm{J}$, et al. Serum immunoglobulin free light chains in severe forms of atopic dermatitis. Clin Immunol. 2010; (71): 312-6.

13. Kestřánek J, Jílek $P$, Matula $\vee$, et al. Jaký je aktuální stav diagnostiky vulvovaginálního dyskomfortu v České Republice? Česká Gynekologie. 2013; 78 (6): 522-7.

14. Mitchell C, Moreira C, Fredricks D, et al. Detection of fastidious vaginal bacteria in women with HIV infection and bacterial vaginosis. Infectious Diseases in Obstetrics and Gynecology. 2009; (12) Access mode: https://www.ncbi.nlm.nih.gov/pmc/ articles/PMC2777244/. (Date of access: 22.10.19).

15. Жижко Е. В., Чигановой С. Д. Молодая семья: проблемы и перспективы социальной поддержки. Красноярск: РУМЦ ЮO, 2011; 145 c.

16. Fischer GO. Chronic vulvitis in prepubertal girls. Aust J Dermatology. 2010; (51): 118-23. 
17. Lewis WG, Robinson LS, Perry J, et al. Hydrolysis of secreted sialoglycoprotein immunoglobulin $A(\lg A)$ in ex vivo and biochemical models of bacterial vaginosis. J Biol Chem. 2012; 287 (3): 2079-89.

18. Ott MA, Ofner S, Fortenberry JD. Beyond douching: use of feminine hygiene products and STI risk among young women. J Sex Med. 2009; (6): 1335-40.

19. Кохреидзе Н. А., Гуркин Ю. А., Кутушева Г. Ф. и др. Вульвовагинит в раннем детстве. СПб., 2017; 23 с.

20. Зиядуллаев У. Х. Состояние иммунитета при кандидозном вульвовагините у девочек подростков. Проблемы репродукции. 2014; (2): 32-4.

21. Gardner M J, Altman DG. Statistics with confidence. BMJ publications. Reprint. 1994: 51-52.

22. Bjerre LM, LeLorier J. Expressing the magnitude of adverse effects in case-control studies: "the number of patients needed to be treated for one additional patient to be harmed". BMJ. 2000; (320): 503-6.

23. Здравоохранение в России. 2017: Статистический сб. Росстат. Москва, 2017; 170 с. Доступно по ссылке: [http:// www.gks.ru/free_doc/doc_2017/zdrav17.pdf].

24. Кириллова Е. Н., Павлюкова С. А. , Акулич Н. С. Вульвовагинит у детей. Медицинский журнал. 2017; (2): 151-3.

25. Brabin $L$, Roberts SA, Fairbrother $E$, et al. Factors affecting vaginal $\mathrm{pH}$ levels among female adolescents attending genitourinary medicine clinics. Sex Transm Infect. 2005; (81): 483-7.

26. Brotman RM, Erbelding EJ, Jamshidi RM, et al. Findings associated with recurrence of bacterial vaginosis among adolescents attending sexually transmitted diseases clinics. J Pediatr Adolesc Gynecol. 2007; (20): 225-31.

27. Donders GG, et al. Vaginal cytokines in normal pregnancy. American journal of obstetrics and gynecology. 2003; (189): 1433-8. 